Драгана Поповић

Универзитет у Новом Саду

Филозофски факултет

Одсек за славистику

dragana.popovic@gmail.com
УДК 811.161.1'354

https://doi.org/10.18485/slavistika.2020.24.2.18

стручни рад

примљено 17.03.2020.

прихваћено за штампу 18.09.2020.

\title{
РЕАЛИЗАЦИЈА РУСКИХ ФОНЕМА /Е/ И /А/ КРОЗ ПРИЗМУ ОРТОГРАФСКИХ ГРЕШАКА КОРИСНИКА ИНТЕРНЕТА
}

У раду се разматра реализација руских фонема /e/ (графички знак $е$ ) и /a/ (графички знаци $я, a)$ у неакцентованим слоговима иза меких сугласника, тј. у првом и другом степену редукције. Даје се преглед знакова којима се бележе гласови (вокали) у поменутим

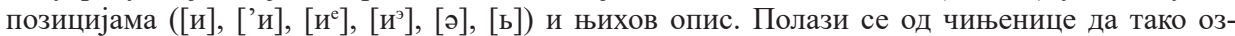
начени и описани гласови странцима не гарантују увек жељени изговор. С друге стране, може се приметити да изворни говорници руског језика показују несигурност при писању одговарајућих графема у наведеним позицијама. Несигурност се огледа у грешкама у виду писања графеме $u$ уместо графеме $e$ и обрнуто (нпр. *дитиктив - детекти́в; *преоритет, *приоретет - приорите́т) и замене графема $e$ и $я$ (нпр. *масляница - ма́сленица, *серебренный сере́бряный). Наведено упућује на закључак да поменуте ортографске грешке изворних говорника руског језика могу странцима бити од помоћи при усвајању изговора разматраних гласова. У раду је анализиран материјал који је настао као резултат активности корисника руског сегмента интернета.

Кључне речи: руски језик као страни, фонетика, фонема, ортографија, ортоепија, фонетска транскрипција.

The paper discusses the realization of the Russian phonemes /e/ (graphic sign $e$ ) and /a/ (graphic signs $, a, a$ ) in unstressed syllables after soft consonants, i.e. in the first and second degrees of reduction. First, we give an overview of the signs which the vowels in the mentioned positions ([и], $\left.[' и],\left[и^{\mathrm{e}}\right],\left[и^{3}\right],[ә],[ь]\right)$ are spelled with and their descriptions. The reason for this lies in the fact that the spelling and the description of the vowels do not always guarantee the desired pronunciation to foreign language learners. On the other hand, it has been noted that native speakers of Russian show uncertainty in writing the appropriate graphemes in these positions. They make mistakes in using the grapheme и instead of the grapheme e and vice versa (е.g. *дитиктив - детекти́в; *преоритет, *приоретет - приорите́т) and interchanging the graphemes $e$ and $я$ (е.g. *масляница - ма́сленица, *серебренный - сере́бряный). All this leads to the conclusion that the mentioned orthographic errors of Russian speakers can be useful for Russian language learners in mastering the pronunciation of the vowels in question. The analyzed material comes from a corpus of texts written by Russian users of the Internet.

Keywords: Russian as a foreign language, phonetics, phonemes, orthoepy, orthography, phonetic transcription.

Увод. Изговор је један од најсложенијих аспеката учења страног језика, а тиме и постизања језичке компетенције. Студије руског језика пружају знања из области фонетике која се, између осталог, односе на опис гласова и њихово обележавање путем фонетске транскрипције. Дата знања подразумевају информације о положају говорних органа и њиховој улози у образовању сугласника и самогласника, тј. упознавање са сугласничким и самогласничким системом руског језика чија се сложеност темељи на различитим диференцијалним 
особинама. Код сугласника су то тврдоћа - мекоћа, начин и место творбе, звучност - безвучност, а код самогласника кретање језика по вертикали (висина), кретање језика по хоризонтали (ред), учешће усана. Наведена знања, потпомогнута фонетском транскрипцијом, значајна су за усвајање изговора, али често нису довољна. Савладавању ове компоненте при изучавању страног језика умногоме доприноси слушање и опонашање, у идеалном случају, изворних говорника, али се дешава да чак ни они не могу увек са сигурношћу да одреде који глас изговарају у одређеним позицијама. ${ }^{1}$ У складу с тим, овај рад представља покушај да се помоћу данас доступних извора додатно осветли мали сегмент везан за изговор неких гласова руског језика.

Изговор вокала руског језика у првом реду зависи од тога да ли се они налазе у акцентованом (јак положај) или неакцентованом слогу (слаб положај), будући да вокали у неакцентованим слоговима подлежу редукцији - квантитативној (краћи су и слабији од акцентованих) и квалитативној, која подразумева промене у изговору вокала у односу на његово звучање у акцентованом слогу. На тај начин једна вокалска фонема може имати различиту гласовну реализацију, нпр. акустички различити гласови сврставају се у фонему /e/2: u’éльй, места́, перенесена́. У овом раду у центру интересовања је гласовна реализација фонема /e/ и /a/ у неакцентованим слоговима иза меких сугласника.

2. ГЛАСОВНА РЕАЛИЗАЦИЈА ФОНЕМА /Е/ И /А/ У НЕАКЦЕНТОВАНИМ СЛОГОВИМА изА МЕКИХ СУГЛАСНИКА. У руској литератури која садржи информације о гласовном систему руског језика (Брызгунова 1977; Аванесов 1984; Шанский и др. 1987; Касаткин 2003; Панков и др. 2004; Савкова 2007; Скрипник и др. 2010) за означавање вокала у неакцентованим слоговима на месту слова $e$ и $r^{3}$ (вокали у позицији иза меких сугласника) у транскрипцији се употребљавају различити знаци: [и], ['и], [и'], [иㅜㄹ, [ə], [ь]. Разлика се примећује и код описивања датих гласова, чији се изговор одређује у односу на степен редукције, тј. у односу на то да ли је реч о првом предакценатском слогу (први степен редукције) или о осталим неакцентованим слоговима (други степен редукције).

2.1. Први СтЕПЕН РЕДУКцИЈЕ. Глас који се на месту слова $e$ и $я$ изговара у првом предакценатском слогу иза меких сугласника означава се и описује на следеће начине:

1) кратки слаби вокал [и]; иза [j] и [i] вокал сличан [и]:

$e-$ [свитло́] $\left(\right.$ светло́) ${ }^{4}$

${ }^{1}$ Одређивање изговора вокала у постакценатским слоговима иза меких сугласника у руском језику понекад представља потешкоћу чак и за фонетичара, будући да се могу срести неодређени гласови прелазног карактера које је потребно сврстати у одговарајући акустички тип. Наведене потешкоће потврђују и резултати истраживања према којима највећи број испитаника не може да одреди изговорене гласове обележене вокалима у постакценатским слоговима иза меких сугласника (Крысин и др. 1974: 111-112).

${ }^{2}$ Одговарајући глас, у зависности од извора, обележава се знацима э или $e$.

${ }^{3}$ После сугласника [ч] и [ш:] реч је о графичком знаку $a$.

${ }^{4}$ Фонетска транскрипција наводи се према изворницима. У приручнику (Панков и др. 2004: 45) за означавање гласа у овом положају употребљава се знак ['и]: [придм’́т] (предме́m). 


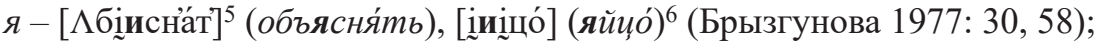

2) глас близак [и]; донекле ослабљен глас предњег реда, средњи између [и] и [e] по степену уздигнутости језика - [ә] ${ }^{7}$ (језик је у нижем положају него при изговору [и], а у вишем него при изговору [e]):

$e-[$ дə]ре́вня (дере́вня), [рә’]ка́ (река́)

я-[м’]сни́к (мясни́к), [рә’]би́на (ряби́на) (Аванесов 1984: 95);

3) глас $[и]$ са склоношћу према $[\mathrm{e}]-\left[\mathrm{u}^{\mathrm{e}}\right]$ :

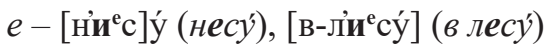

я-[піи те та́к (пята́к) (Шанский и др. 1987: 111); 8

4) ослабљен глас $\left[и^{э}\right]$ :

$e-$ [ліи до́к] (ледо́к), [п̈ишком] (пешко́м)

я - [пй ${ }^{3}$ та́к] (пята́к) (Скрипник и др. 2010: 10);

5) $\left[\mathbf{h}^{\ni}\right]$ :

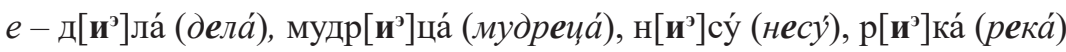

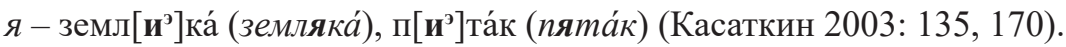

2.2. ДРУГИ СТЕПЕН РЕДУКцИЈЕ. ГЛас који се на месту слова $e$ и $я$ изговара у постакценатским и у осталим слоговима иза меких сугласника означава се и описује на следеће начине:

1) глас близак [и]; средњи између [е] и [и] по степену уздигнутости језика [ə] (много редукованији него у првом предакценатском слогу):

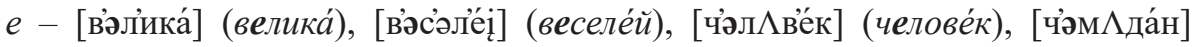

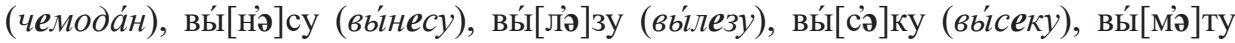

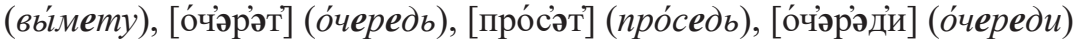

${ }^{5}$ Глас који се изговара на месту слова $a$ и $o$ на апсолутном почетку речи и у првом предакценатском слогу (иза тврдих сугласника) у литератури се обележава знаковима [ă] и $[\Lambda]$.

${ }^{6}$ Глас који се у разматраној позицији изговара на месту слова $я$ одређује се и као кратко [и]: взглИнул (взгляни́л), тИжелый (тяжёльий); вокал у истој позицији иза сугласника [ч] и [ш:] као кратки глас између [е] и [и]: чИсы́ (часb́l), щИве́ль (щаве́ль), док се за вокал на месту слова $e$ тврди да је ближи вокалу [и]: вИсна (весна́) (Савкова 2007: 53).

7 У овој позицији граница између [и] и [ә] је условна «так как этимологическое [и] само в этом положении в основном массиве слов нейтрального стиля произносится менее энергично, с меньшим подъемом языка, т. е. как [ә]». У складу с тим, изговор вокала на месту графема $я(a)$ и $e$ је много ближи изговору [и] него [е]. Док се у акцентованим слоговима разликују вокали [e], [a] и [и], на месту њихових неакцентованих аналогона после меких сугласника изговара се исти глас (у мањој мери ослабљен у првом предакценатском слогу, а у већој у другим неакцентованим слоговима) обележен знаком [ә]. Другим речима, долази до неутрализације ових вокала, тј. «система безударных гласных не различает разные степени подъема и упрощается до противопоставления [ə] и [у] по признаку отсутствия или наличия лабиализации» (Аванесов 1984: 59, 96-97).

${ }^{8}$ И у домаћој литератури се за варијанту првог степена редукције у транскрипцији употребљава знак $\left[\mathrm{u}^{\mathrm{e}}\right]-$ „ненапрегнут вокал који по степену подизања језика стоји на средини између [е] и [и]”. При томе се наводи да се језик у већој мери подиже према положају за изговор ненаглашеног вокала [и], уколико је следећи сугласник мек: [сиие ло́] (село́), [чйерта́] (черта́), [іјиёз́к] (язьік), [ш:и'едйт] (щади́ть) (Јазић 1977: 38). 


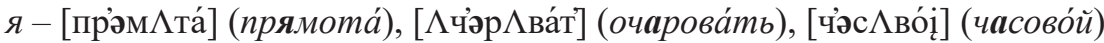

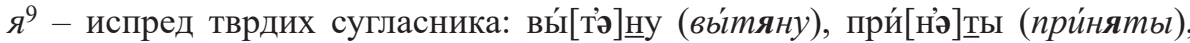

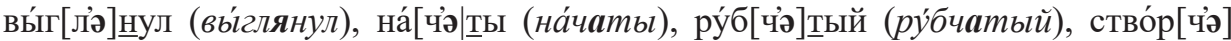
тый (ство́рчатый)

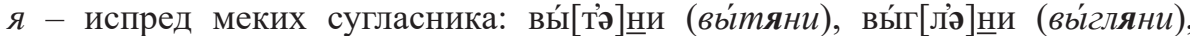

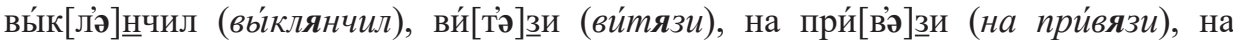
пло́[ш:ə]ди (на пло́щади)

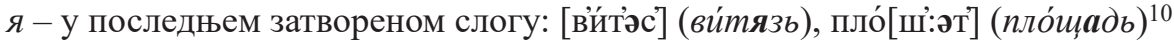
(Аванесов 1984: 97-98);

2) кратки слаби глас [ь]:

$e$ - [вз́сь'лъ] (ве́село) (Брызгунова 1977: 58) ${ }^{11}$;

3) ослабљени или редуковани вокал предњег реда, средње-високи по степену уздигнутости језика («средне-верхнего подъема») - [ь ${ }^{12}$ :

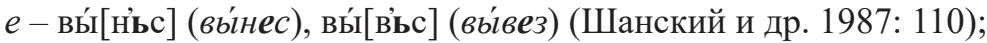

4) у односу на $\left[\mathbf{u}^{3}\right]$ још слабији глас [ь]:

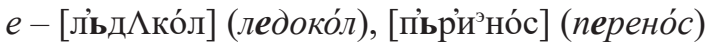

я-[піьт Аки́] (пятаки́) (Скрипник и др. 2010: 10);

5) $\left[и^{3}\right]:$

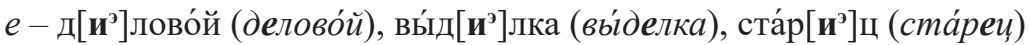

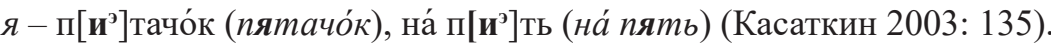

Из свега наведеног се може видети да се изговор неакцентованих вокала иза меких сугласника, с једне стране, у свим позицијама изједначава, док се, с друге стране, покушава указати на разлику између вокала у првом предакценатском и осталим слоговима. У складу с тим, говори се о неутрализацији [а], [е] и [и] у

${ }^{9}$ Глас [ə] изговара се на месту слова $я(a)$ и у постакценатским слоговима (не у наставцима) испред тврдих и меких сугласника, као и у последњем затвореном слогу (Аванесов 1984: 98-99). О вокалима на месту слова $e$ и $я(a)$ после меких сугласника у граматичким наставцима в. (Аванесов 1984: 99-101).

10 У последњем постакценатском затвореном слогу иза меких сугласника на месту слова $я$ (a) (не у наставку) напоредо с [ә] (гласом блиским [и]) може се изговарати и отворенији глас

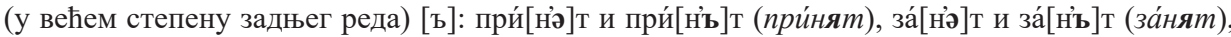
на́[ч’’]т и на́[ч’ъ]т (на́чат) (Аванесов 1984: 98-99).

${ }^{11}$ Глас који се изговара иза [i] и [i] описује се као вокал сличан [и]: [мо́іьц:ъ] (мо́ется), те се напомиње да се у крајњим слоговима вокали изговарају јасније чиме се избегава мешање

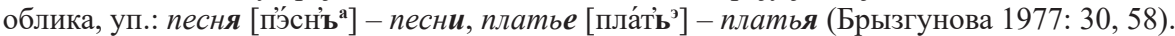

12 Једнако означен глас који се у постакценатским слоговима изговара на месту слова $e$ одређује се и као ближи вокалу [и]: трепьт (тре́nет) (Савкова 2007: 53). За варијанту другог степена редукције исти знак употребљава се и у домаћој литератури: [ч’ылӑве́к] (челове́к),

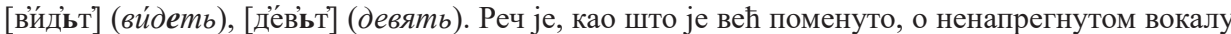
између [e] и [и] по степену подизања језика. Дати глас је у разматраним позицијама редукован у већој мери него у слогу непосредно испред наглашеног вокала (Јазић 1977: 38). У приручнику (Панков и др. 2004: 45) за глас који се изговара у неакцентованим слоговима (осим првог предакценатског) употребљава се знак [ь] (кратки глас близак гласу [и]): [прь̇дика́т] (предика́m), [ко́мплькс] (ко́мплекс). 
једном вокалу: «<..> в нейтральном стиле произносится ослабленный (в меньшей степени в 1-м предударном слоге, в большей степени - в других безударных слогах) гласный, средний между [и] и [е], более близкий к [и], который обозначаем знаком — [ә] < ..>». УП.: [мәла́] (мила́ и мела́), [увәда́т] (увяда́ть и увида́mь), [ләса́] (леса́ и лиса́), [ви́тәнну], [ви́н’әсу], [ви́л’зу] (Аванесов 1984: 59-60).

Без обзира на то о којем је начину означавања гласова реч, оно не гарантује у анализираним позицијама одсуство јасног изговора гласова [а] и [е] код странаца. ${ }^{13}$ Такав изговор доводи се, наравно, у везу са словним саставом речи («буквенное произношение»). Тако слово е у оквиру речи (нпр. сестра́), без обзира на знање њеног гласовног састава (фонетске транскрипције), може проузроковати изговор у корист вокала [е]. Исто тако, слово я (нпр. язи́кк) може утицати на изговор у корист вокала [a]. На говорнике српског језика утиче и разлика у изговору речи двају језика које имају исти словни састав, уп.: срп. сѐстра : рус. сестра́; срп. ре́ка : рус. река́. С друге стране, наведено помаже говорницима српског језика да избегну ортографске грешке тамо где их изворни говорници руског језика могу правити. И управо њихове ортографске грешке могу бити корисне при усвајању изговора овде анализираних гласова.

3. МАТЕРИЈАЛ ИЗ ЕЛЕКТРОНСКИХ ИЗВОРА. Изражавање путем интернета подразумева активност великог броја људи и представља извор различитих информација. Тако праћење писаног материјала на руском сегменту интернета омогућава издвајање информација везаних за изговор појединих гласова датог језика. Реч je о томе да интернет пружа могућност изражавања људима различитог степена образовања што повећава вероватност појаве неправилно написаних речи. Истовремено, тако написане речи и представљају извор информација о томе које гласове у одређеним позицијама подразумевају говорници руског језика. Богат извор оваквих информација представљају и подаци о грешкама које се прикупљају у оквиру пројекта Работа над ошибками компаније Яндекс (уandex.ru). Реч je o грешкама које праве корисници претраживача дате компаније, нпр.

- међусобна замена слова $е$ и $u$ :

привере́дливый: *превиредлевый

эликси́р: *элексир

прецеде́нт: *прицедент

Геленджи́к: *Гиленджи́к

забере́менеть: *забиременеть

13 „Акање” («яканье»: заглЯнуть, объЯвление, поЯвление, проЯвить, разъЯснить, развЯзать, посвЯщение, разьЯренный, Язык) се доживљава као дијалектизам или као «акцентная речь нерусского человека», а не звуче руски ни речи с јасним изговором вокала [е] на крају придева у множини: синиЕ, красныЕ, добрыЕ, быстрыЕ, промышленныЕ, хозяйственныЕ, смелыЕ. У том положају вокал [е] по ортоепским законима звучи као кратко [и] («ДобрыЬ, смелыЬ люди», «ПромышленныЬ предприятия», «КрасныЬ, белыЬ, желтыЬ, черныЬ розы»), а обележава се знаком Ь (Савкова 2001: 53-54). О изговору гласова на месту слова $e$ и $я(a)$ у различитим стиловима в. у (Аванесов 1984: 96-97). 


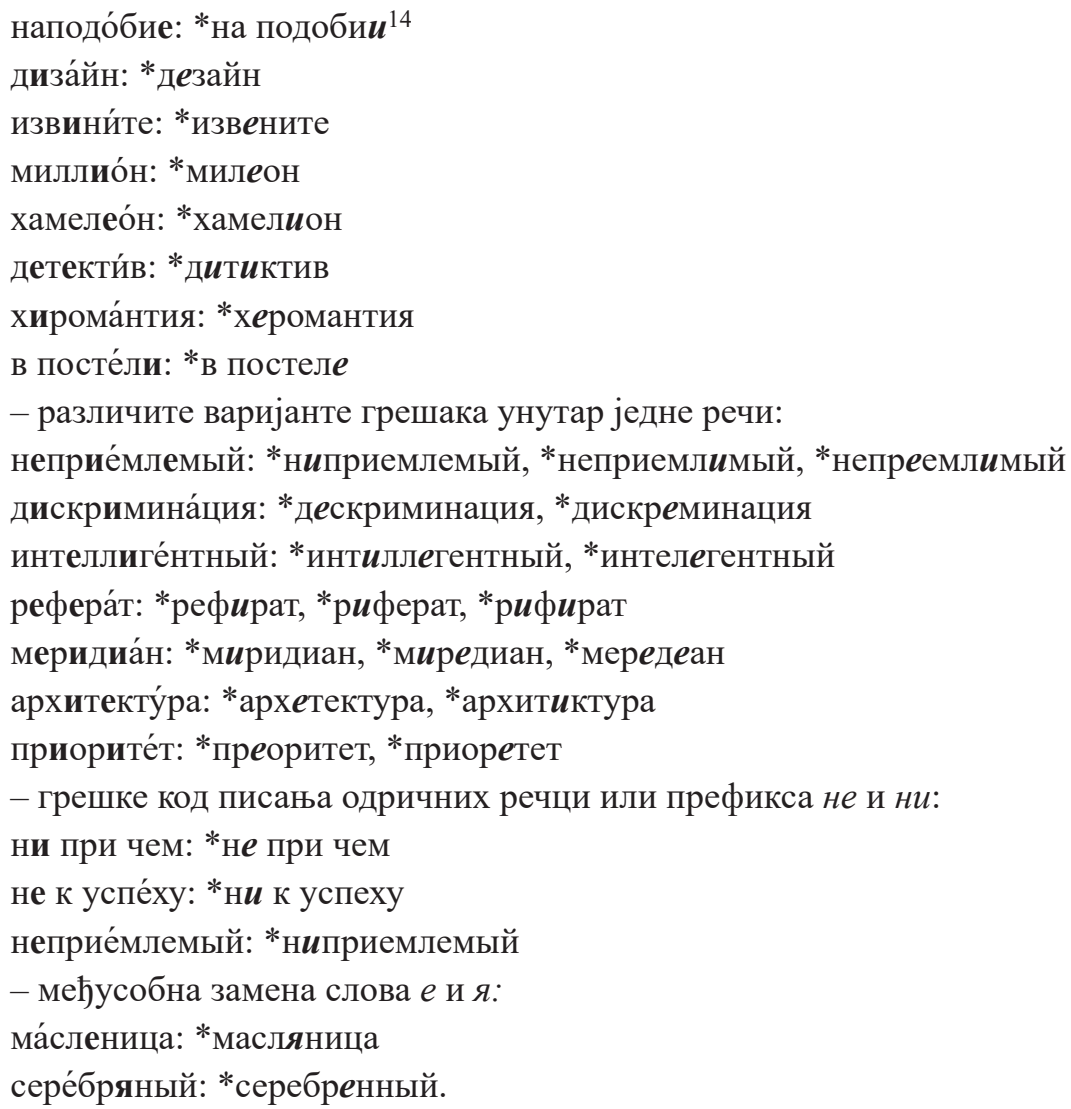

На исто указују и други извори који садрже неправилно написане речи или питања о правилним облицима речи, при чему је приметна учесталост грешака код писања речи страног порекла и писања речци или префикса не, $н и$ :

Коррупция как способ лигитимации власти (law.edu) - наслов чланка

Автор статьи делитант, либо сознательно манипулирует читателями, используя их безграмотность. (ria.ru) - коментар уз новински чланак

Как правильно написать: легетимный, легитимный, лигитимный, лигетимнbiц̌? (bolshoyvopros)

Что такое гигимон? (otvet.mail.ru)

Ни при чем или не при чем - как писать правильно? (marmore)

«Не один» или «ни один»: как правильно писать? (bolshoyvopros)

Међутим, и у другим случајевима корисници интернета показују несигурност у вези са словима на позицијама вокала [е], [а] и [и] нарочито ако су они део именичких или глаголских наставака:

${ }^{14}$ Не обележавају се ортографске грешке које нису предмет ове анализе: *на подобии (наподобие), *милеон (миллион), *интелегентный (интеллигентный), *серебренный (серебряный). 
Как правильно писать, «и» или «е» в словах «выбИраем», «выбЕрите»? (bolshoyvopros)

Как правильно писать: сколько стоит или стоят эти книги? (znanija)

Как узнать, что писать в коние сущуествительного («Е» или «И»)? (otvet. mail.ru)

Как понять, где пишется окончание «Е» или «И»? Например, на праздник... (znanija)

Как определить, что писать на конце глаголов -е или -и? Например, в каком ряду в обоих словах пропущена буква E? 1) перемел..шь, выдвига..мый, 2) прибегн..шь, выправ..вший, 3) залез..шь, разве..нный, 4) задума..шь, нянч..вший (otvet.mail.ru)

Подскажите, в каких случаях в коние слова пишется «я», а в каких «е»? (otvet.mail.ru)

Изворни говорници руског језика, који нису сигурни у словни састав речи, могу правити ортографске грешке у позицијама графичких знакова $e$ и $u$ (у случају када они означавају неакцентоване вокале), будући да на тим позицијама изговарају исти глас. Одличан пример за то су речи у којима је присутна двострука или чак вишеструка замена поменутих слова. Тако се на месту слова $u$ појављује $e$ и обрнуто - $е$ у позицији $u$ : *превиредлевый - привере́дливый, *интиллегентный интеллиге́нтный, *миредиан - меридиа́н, *непреемлимый - неприе́млемый.

Међутим, остаје и даље питање звучања и изговора гласова у разматраним позицијама. Да је реч о гласу веома блиском [и] првенствено потврђују грешке са словом $u$ на месту $е$ (*прицедент - прецеде́нт, *Гиленджи́к - Геленджи́к, *хамелион - хамеле́́н, *риферат - рефера́т, *рефират - рефера́т, *ниприемлемый - неприе́млемый, *неприемлимый - неприе́млемый, *ни к успеху - не к успе́ху, *забиременеть - забере́менеть, *лигитимная - легитимная, *миридиан - меридиа́н, *дитиктив - детекти́в, *гигимон - гегемо́н). ${ }^{15}$ Истовремено, ортографске грешке које су резултат писања слова $e$ на месту слова $u$ не указују на изговор у корист вокала [е], већ говоре о несигурности код избора правилног слова управо због истоветног изговора гласова у позицијама поменутих графичких знакова: *элексир - эликси́р, *дескриминация - дискримина́ция, *дискрем $и$ нация - дискримина́ция, *херомантия - хирома́нтия, *извените - извини́те, * не при чём - ни при чём, *дезайн - диза́йн, *в постеле - в посте́ли, *преоритет - приорите́т, *приоретет - приорите́т, *интелегентный - интеллиге́нтный, *мередеан - меридиа́н. ${ }^{16}$

15 У савременом руском књижевном језику доминира икање («иканье»), тј. подударање

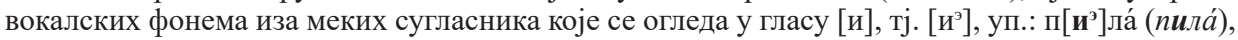

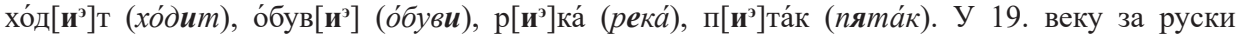
књижевни језик било је карактеристично екање («эканье») које на истим местима подраз-

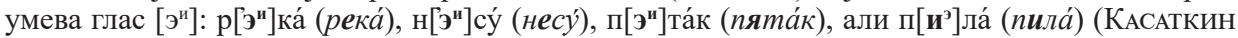
2003: 170).

${ }^{16}$ Међусобна замена слова $e$ и $u$ примећена је и иза тврдих сугласника, нпр. инциде́нт *инцедент, официа́льный - *офицеальный, недви́жимость - *недвижемость. Говорници руског језика у овим се позицијама двоуме између слова $e$ и $u$ јер се у предакценатским слоговима (редукција је слабија у првом предакценатском слогу) на месту слова $e$ изговара вокал 
Гласовну реализацију фонеме /a/ у неакцентованим слоговима иза меких сугласника, тј. на месту слова, , ортографске грешке посредно откривају. Чињеница да се у истим позицијама замењују слова $е$ и я (*масляница - ма́сленица, *ceребренный - сере́бряный) говори у прилог изједначавања гласова који се датим словима обележавају, што значи да се и фонема /a/ у анализираним позицијама реализује као глас веома близак гласу [и].

Наведене ортографске грешке тако потврђују да се фонеме /e/ и /a/ у ненаглашеним слоговима иза меких сугласника у изговору изворних говорника руског језика неутралишу у гласу веома блиском [и] и то у свим позицијама, тј. без обзира на степен редукције: рефера́т - *рефират; детекти́в - *дитиктив; гегемо́н - *гигимон; дискримина́ция - *дескриминация, *дискреминация; эликси́р *элексир; ма́сленица - *масляница.

4. ЗАкључАк. Будући да се приликом реализације фонема /a/ и /e/ у неакцентованим слоговима (у првом предакценатском слогу и у осталим неакцентованим слоговима) иза меких сугласника (на месту графичких знакова $e$ и $я / a$ ) код странаца који уче руски језик примећује „акање” и „екање”, ортографске грешке изворних говорника руског језика могу бити од помоћи при усвајању изговора гласова у наведеним позицијама. Реч је о томе да ортографске грешке непосредно или посредно показују које гласове изворни говорници руског језика имају у виду у датим позицијама. Њихове грешке потврђују да је за савремени руски језик карактеристично „икање” које подразумева неутрализацију гласова означених словима $e, я / a$ и $u$ у неакцентованим слоговима иза меких сугласника, оличену у гласу веома блиском гласу [и] или чак једнаком њему.

\section{Цитирана литература}

Аванесов, Рубен И. Русское литературное произношение. Москва: Просвещение, 1984.

[Avanesov, Ruben I. Russkoe literaturnoe proiznoshenie. Moskva: Prosveshchenie, 1984]

Брызгунова, Елена А. Звуки и интонация русской речи. Москва: Русский язык, 1977.

[Bryzgunova, Elena A. Zvuki i intonaciâ russkoŭ rechi. Moskva: Russkij iāzyk, 1977]

Јазић, Ђорђе. Основи фонетике руског језика: руски гласовни систем у поређењу са српскохрватским. Београд: Научна књига, 1977.

[Jazić Đorđe. Osnovi fonetike ruskog jezika: ruski glasovni sistem u poređenju sa srpskohrvatskim. Beograd: Naučna knjiga, 1977]

Касаткин, Леонид Л. Фонетика современного русского литературного языка. Москва: Изд-во МГУ, 2003.

[Kasatkin, Leonid L. Fonetika sovremennogo russkogo literaturnogo iāzyka. Moskva: Izd-vo MGU, 2003]

Крысин, Леонид П., Вера Л. Воронцова, Марина Я. Гловинская, Елена И. Голанова, Надежда Е. Ильина, Маргарита В. Китайгородская, Светлана М. Кузьмина. Русский язык по данным массового обследования (опыт социально-лингвистического изу-

«по своему качеству средний между отодвинутым назад [э] и [ы], который обозначим через $\left[\mathrm{b}^{\ni}\right] \gg$, док се у постакценатским слоговима изговара глас средњег реда и средње висине [ъ] (Аванесов 1984: 94). 
чения). Москва: Наука, 1974.

[Krysin, Leonid P., Vera L. Vorontŝova, Marina Iâ. Glovinskaiā, Elena I. Golanova, Nadezhda E. Il'ina, Margarita V. Kită̌gorodskaiā, Svetlana M. Kuz'mina. Russkiǐ iāzyk po dannym massovogo obsledovaniia (opyt sotșal'no-lingvisticheskogo izucheniia). Moskva: Nauka, 1974]

Панков, Федор И., Елена Л. Бархударова. Русская фонетика и интонация: Практическое пособие для иностранных магистрантов-лингвистов. Москва: Изд-во Моск. ун-та, 2004.

[Pankov, Fedor I., Elena L. Barkhudarova. Russkaiā fonetika i intonatșiiâ: Prakticheskoe posobie dlia inostrannykh magistrantov-lingvistov. Moskva: Izd-vo Mosk. un-ta, 2004]

Савкова, Зинаида В. Искусство оратора. Москва: ИВЭСЭП; Знание, 2007. <http:// www.studfiles.net/ preview/395684>05.02.2018.

[Savkova, Zinaida V. Iskusstvo oratora. Moskva: IVÈSÈP; Znanie, 2007. <http:// www. studfiles.net/preview/ 395684> 05.02.2018]

Скрипник, Яна Н., Тамара М. Смоленская. Фонетика современного русского языка. Учебное пособие. Ставрополь: Изд-во СГПИ, 2010.

[Skripnik, Iâna N., Tamara M. Smolenskaiâ. Fonetika sovremennogo russkogo iāzyka. Uchebnoe posobie. Stavropol': Izd-vo SGPI, 2010]

Шанский, Николай М., Валерий В. Иванов. Современный русский язык. В трех частях. Часть I. Москва: Просвещение, 1987.

[Shanskiĭ, Nikolaŭ M., Valeriǐ V. Ivanov. Sovremennyĭ russkiı̌ iâzyk. V trekh chastiakh. Chast' I. Moskva: Prosveshchenie, 1987]

\section{Извори}

$<$ http://www.bolshoyvopros.ru/questions/1721149-ne-odin-ili-ni-odin-kak-pravilnopisat.html $>10.03 .2018$.

$<$ http://www.bolshoyvopros.ru/questions/576099-kak-pravilno-pisat-legetimnyjlegitimnyj-ligitimnyj-ligetimnyj .html $>10.03 .2018$.

$<$ http://www.bolshoyvopros.ru/questions/1447094-kak-pravilno-pisat-i-ili-e-vslovah-vybiraem-vyberite-pochemu.html $>15.02 .2018$.

$<$ http://www.law.edu.ru/doc/document.asp?docID $=1224478>10.03 .2018$.

$<$ http://www.otvet.mail.ru/question/75989968> 15.02.2018.

$<$ http://www.marmore-text.ru/ni-pri-chem-ili-ne-pri-chem-kak-pisat-pravilno.html $>$ 03.02.2018.

$<$ https://www.otvet.mail.ru/question/40407254> 15.02.2018.

$<$ https://www.otvet.mail.ru/question/28797201> 15.02.2018.

$<$ https://www.otvet.mail.ru/question/44594319>10.03.2018.

$<$ https://www.ria.ru/20191209/1562066714.html?rcmd_alg=collaboration2> 09.12.2019.

$<$ https://www.yandex.ru/> 02.02.2018, 15.02.2018, 10.03.2018.

$<$ https://www.znanija.com/task/10084730>02.02.2018.

$<$ https://www.znanija.com/task/7842595> 15.02.2018. 
Драгана Попович

\title{
РЕАЛИЗАЦИЯ РУССКИХ ФОНЕМ /Е/ И /А/ ЧЕРЕЗ ПРИЗМУ ОРФОГРАФИЧЕСКИХ ОШИБОК ИНТЕРНЕТ-ПОЛЬЗОВАТЕЛЕЙ
}

\begin{abstract}
Резюме
В данной статье орфографические ошибки носителей русского языка, найденные в интернете, используются в качестве источника информации, способствующего исправлению орфоэпических ошибок иностранцев, изучающих русский язык. Речь идет о голосовой реализации фонем /e/ (графический знак $e$ ) и /a/ (графические знаки $я, a)$ в безударных слогах после мягких согласных (в первом предударном слоге и во всех остальных безударных слогах). Произношение звуков в названных позициях часто с трудом осваивается иностранцами. Анализ слов, неправильно написанных людьми, для которых русский язык является родным, показал, какие звуки они произносят в рассматриваемых позициях, что может помочь иностранцам в освоении произношения данных звуков.

Ключевые слова: русский язык как иностранный, фонетика, фонема, орфография, орфоэпия, фонетическая транскрипция.
\end{abstract}

